\title{
Benthic amphipod community in the northern Bering Sea: analysis of potential structuring mechanisms
}

\author{
K. O. Coyle, R. C. Highsmith \\ Institute of Marine Science, School of Fisheries and Ocean Sciences, University of Alaska Fairbanks, Fairbanks, \\ Alaska 99775-1080, USA
}

\begin{abstract}
The age class structure of ampeliscid populations is determined largely by competition for space. Population densities of the various ampeliscid species are regulated by a balance between required carbon flux rates to the seafloor, predation rates, competition for space and reproductive potential. The largest taxa require high organic matter input and low predation rates to mature and reproduce. Reductions in organic matter flux favor smaller taxa. Low predation rates favor larger taxa, which can out-compete the smaller taxa for available space. High predation rates favor smaller taxa, which have a higher reproductive rate and are therefore more effective colonizers. The above factors can explain the relative concentrations of Ampelisca macrocephala, Ampelisca birulai and Byblis spp., the most abundant ampeliscids in the northern Bering Sea. Elevated predation losses to gray whales will depress the density of the large-sized $A$. macrocephala populations and increase the density of the smallest species, $A$. birulai. Global warming should elevate ampeliscid food requirements, and may also lead to elevated predation rates, both selecting for smaller species.
\end{abstract}

KEY WORDS: Ampeliscids - Competition - Predation - Bering Sea

\section{INTRODUCTION}

The northern Bering Sea benthic amphipod community, covering an area of about $40000 \mathrm{~km}^{2}$ in the Chirikov Basin, is one of the most productive benthic communities on record (Highsmith \& Coyle 1990). The community is composed primarily of tube-building amphipods of the family Ampeliscidae (Stoker 1981, Grebmeier et al. 1989, Highsmith \& Coyle 1991, 1992) and is the primary food source of the California gray whale Eschrichtius robustus (Blokhin \& Vladimirov 1981, Nerini 1984). One of the largest ampeliscids in the Chirikov Basin is Ampelisca macrocephala, which reaches lengths of over $30 \mathrm{~mm}$ and is a dominant component of the benthic community, accounting for about $70 \%$ of amphipod biomass and production in the ampeliscid bed (Highsmith \& Coyle 1992). The high abundance and large size of $A$. macrocephala make it a preferred prey for gray whales. Thus, the gray whale population is heavily dependent upon ecological conditions favoring high densities of large benthic amphipods.

The ampeliscid community in the Chirikov Basin is composed of 8 species, varying in adult size from about $10 \mathrm{~mm}$ to over $30 \mathrm{~mm}$ (Coyle \& Highsmith 1989). Therefore, the large Ampelisca macrocephala species is not necessarily the only amphipod grazer which could fill the niche it currently occupies. A smaller species could presumably dominate, given the proper environmental conditions. Factors affecting amphipod community structure include organic matter flux to the bottom, fecundities, growth rates, inter- and intraspecific competition and predation. The relative influence of each of the above factors on Arctic ampeliscid community structure was evaluated using conventional modeling techniques.

The biology of ampeliscids makes them particularly easy to model. They are essentially sedentary infaunal 
organisms. Thus, their population structure can be easily assessed and simulated without the complication of massive emigration or immigration. Ampeliscids are brooders with crawl-away juveniles. Their fecundity and recruitment are, therefore, comparatively easy to measure and simulate over time, in contrast to taxa with planktonic dispersal phases in their life histories. The model presented here is not designed to precisely predict ampeliscid populations, but rather to demonstrate how food supply, reproductive rates, space competition and predation can interact to permit 3 ecologically very similar species to coexist and thrive in the Chirikov Basin ampeliscid bed.

\section{METHODS}

The study site is located in the Chirikov Basin, northern Bering Sea, between $64^{\circ}$ and $65^{\circ} \mathrm{N}$ and $168^{\circ}$ and $170^{\circ} \mathrm{W}$. Environmental data on the Chirikov Basin are available in the literature (Coachman et al. 1975 , Grebmeier et al. 1988, 1989, Highsmith \& Coyle 1990, Coachman \& Hansell 1993).

Sampling was conducted from 1986 through 1988 Four cruises were made to the study site each year during the ice-free period, from late May through early November. Twenty station locations were selected at random and occupied once during each cruise, weather and ice conditions permitting. Five replicate samples were collected at each site with a $0.1 \mathrm{~m}^{2}$ van Veen grab. The samples were sieved through a $1 \mathrm{~mm}$ screen and all animals retained on the screen were preserved in $10 \%$ buffered formalin for later sorting and analyses. Supplemental ampeliscid samples were collected at 3 stations in the bed, the amphipods were sorted to species, measured to the nearest $\mathrm{mm}$ (tip of head to tip of telson), dried at $60^{\circ} \mathrm{C}$ for $24 \mathrm{~h}$, frozen and returned to the laboratory. In the laboratory the amphipods were thawed, redried at $60^{\circ} \mathrm{C}$ for $12 \mathrm{~h}$, and dry weight was determined with a Cahn electrobalance. The amphipods were placed in foil, combusted in a muffle furnace at $600^{\circ} \mathrm{C}$ for $12 \mathrm{~h}$ and reweighed following cooling to determine ash weights.

Respiration rate measurements were made on ampeliscids at sea to determine their carbon demand. Experimental amphipods were collected as outlined above, transferred to sea water taken from just above the bottom, and placed in an incubator adjusted to ambient bottom-water temperatures $\left(0\right.$ to $\left.2^{\circ} \mathrm{C}\right)$. Bottom sediments from the grab samples were rinsed through the $1 \mathrm{~mm}$ screen, allowed to settle and used in the incubation chambers. The incubation chambers consisted of $2.6 \mathrm{~cm}$ diameter plastic tubes 30 to $50 \mathrm{~cm}$ long. The chambers were pushed into the sediment to between 11 and $19 \mathrm{~cm}$ depth and pulled out, thus extract- ing a core. The remainder of the tube volume was filled with bottom water, the chamber was capped at both ends with rubber stoppers and placed in the incubator for several hours until the silt settled from the water. Water volume in the chambers $(250$ to $450 \mathrm{ml}$ ) was adjusted relative to the size of the experimental amphipods such that oxygen concentration decreased by about $10 \%$ during the incubations.

After settling, 1 to 3 ampeliscids were added to each chamber, except for 2 chambers which served as controls. The chambers were placed in the incubator for an additional 2 to $4 \mathrm{~h}$, until the amphipods had burrowed into the sand and settled down. The water was then pipetted from each tube and bottom water was added. Oxygen samples were collected from the bottom water to serve as initial values. The tubes were corked shut such that no bubbles remained in the chambers, and they were placed in the incubator for an additional 9 to $12 \mathrm{~h}$. Two samples for oxygen determination were then drawn from each chamber, and the amphipods were removed from the chambers, dried and weighed as described above. Oxygen determinations were done using a standard micro-Winkler technique (mean precision of $n$ determinations $= \pm 0.003 / \mathrm{n}^{0.5} \mathrm{mg}$-at. $1^{-1}$ Strickland \& Parsons 1972).

Ampeliscids in the formalin preserved samples were sorted to species, measured as described above and enumerated. Eggs were washed from the brood pouch of females and counted. An INGRES data base system was used for analyses and modeling was done using fortran with IMSL subroutines and MATLAB computational and imaging software. The amphipod model in MATLAB programming language is available from the authors on request.

The Byblis species in the northern Bering Sea are very similar and cannot be reliably distinguished when under about $8 \mathrm{~mm}$ length (Coyle \& Highsmith 1989). Therefore all Byblis under $8 \mathrm{~mm}$ were pooled under Byblis spp., which included $B$. gaimardi, $B$. breviramus, $B$. pearcyi, $B$. frigidis and $B$. robustus, comprising approximately $58 \%, 6 \%, 17 \%, 19 \%$ and $<1 \%$ of the identifiable individuals respectively. Since juveniles could not be identified, these taxa were pooled for simulation and data presentation. Approximately $1.4 \%$ of the Byblis spp. were above $22 \mathrm{~mm}$ length. These specimens were primarily $B$. frigidis. Since $B$. frigidis could not be modeled separately, Byblis over $22 \mathrm{~mm}$ length were excluded from the model. Ampelisca macrocephala and Ampelisca erythrorhabdota cannot be distinguished when under about $8 \mathrm{~mm}$ length. Therefore, all $A$. macrocephala and $A$. erythrorhabdota under $8 \mathrm{~mm}$ length were pooled as $A$. macrocephala. Identifiable $A$. erythrorhabdota comprised about $16 \%$ of the 2 taxa pooled. The $A$. macrocephala age class 1 in the data tables includes an unknown number of $A$. erythrorhabdota. 


\section{RESULTS}

The ash free dry weight (AFDW) of Ampelisca macrocephala, Ampelisca birulai and Byblis spp. was regressed on body lengths, yielding the regression coefficients in Table 1A. The regression lines for $A$. macrocephala and Byblis spp. were essentially identi$\mathrm{cal}_{i}$ the line for $A$. birulai was slightly above that of $A$. macrocephala and Byblis spp. (Fig. 1A). The above relationships have certain implications, when viewed in the context of the feeding biology and behavior of the animals.

Ampeliscids are tube-dwelling suspension feeders. They obtain their food by positioning themselves ventral side up at the mouth of the tube and creating a posterior to anterior feeding current. The amphipods feed primarily on diatoms in the water column but can also resuspend organic matter from the sediment surface with their second antennae (Highsmith \& Coyle 1991). Because of their sedentary, suspension-feeding life style, the ampeliscids depend upon environmental conditions to bring food to them, rather than foraging

Table 1. Ampelisca macrocephala, Byblis spp., A. birulai. (A) Regression coefficients relating total body length $(L)$ to ash free dry weight (AFDW), where AFDW $=a L^{b}$ (B) Linear regression coefficients relating length of the second antenna to total body length ( $\mathrm{A} / \mathrm{B}$ ratio). (C) Carbon flux to the benthos required for ampeliscids in each size category to grow to the next, assuming the area occupied is equivalent to the area of a circle with a radius of 0.52 (A. birulai), 0.50 (Byblis spp.) and 0.35 (A. macrocephala) body lengths

\begin{tabular}{|cccc}
\hline \multicolumn{2}{l}{$\begin{array}{l}\text { (A) AFDW vs length } \\
\text { A. macrocephala }\end{array}$} & Byblis spp. & A. birulai \\
\hline $\mathrm{r}^{2}$ & 0.99 & 0.98 & 0.98 \\
$a$ & 0.0047 & 0.0058 & 0.0146 \\
$b$ & 2.95 & 2.89 & 2.62
\end{tabular}

(B) Second antenna length vs body length

\begin{tabular}{lccc} 
& A. macrocephala & Byblis spp. & A. birulai \\
\hline $\mathrm{r}^{2}$ & 0.96 & 0.93 & 0.95 \\
Slope (A/B) & 0.35 & 0.50 & 0.52 \\
Intercept & 0.80 & 1.66 & -0.46
\end{tabular}

(C) Carbon flux

Body length $(\mathrm{mm})$

Flux $\left(\mathrm{g} \mathrm{m}^{-2} \mathrm{yr}^{-1}\right)$

A. birulai Byblis spp. A. macrocephala

\begin{tabular}{cccc}
\hline $4-8$ & 49 & 34 & 64 \\
$8-12$ & 67 & 54 & 104 \\
$12-16$ & 83 & 73 & 144 \\
$16-20$ & - & 92 & 182 \\
$20-24$ & - & 110 & 221 \\
$24-28$ & - & - & 260 \\
$28-32$ & - & - & 298 \\
\hline
\end{tabular}

in the environment. Essentially, the amount of food available to the animal at any given time is the flux of organic matter to the bottom within reach of the second antennae. Linear regression analysis indicates that the length of the second antennae relative to body length (A/B ratio; Table $1 \mathrm{~B}$ ) is fairly constant for a given taxon, with the exception of adult terminal-molt males which do not feed. Therefore, as an amphipod grows in length $(L)$, its food requirements will increase by a factor of about $L^{2.6}$ to $L^{2.9}$, depending on the taxon, but the effective foraging area only increases by $L^{2.0}$. With growth, the organic carbon flux rate to the bottom required by an amphipod increases by some approximately constant factor with respect to length.

Organic flux requirements were estimated from respiration rate measurements $(\mathrm{n}=27)$ on Ampelisca macrocephala. There was no apparent relationship between the AFDW of the experimental animals and respiration rate (Fig. 1B). The mean oxygen consumption rate, $0.20 \mu \mathrm{mg}^{-1} \mathrm{AFDW} \mathrm{h}{ }^{-1}(\mathrm{SD}=0.10)$, was converted to the annual carbon requirement $\left(0.94 \mathrm{~g} \mathrm{C} \mathrm{g}^{-1}\right.$ AFDW $\mathrm{yr}^{-1}$ ) and multiplied by the AFDW per individual in each age class, computed from the regression coefficients for body length and AFDW (Table 1A) and
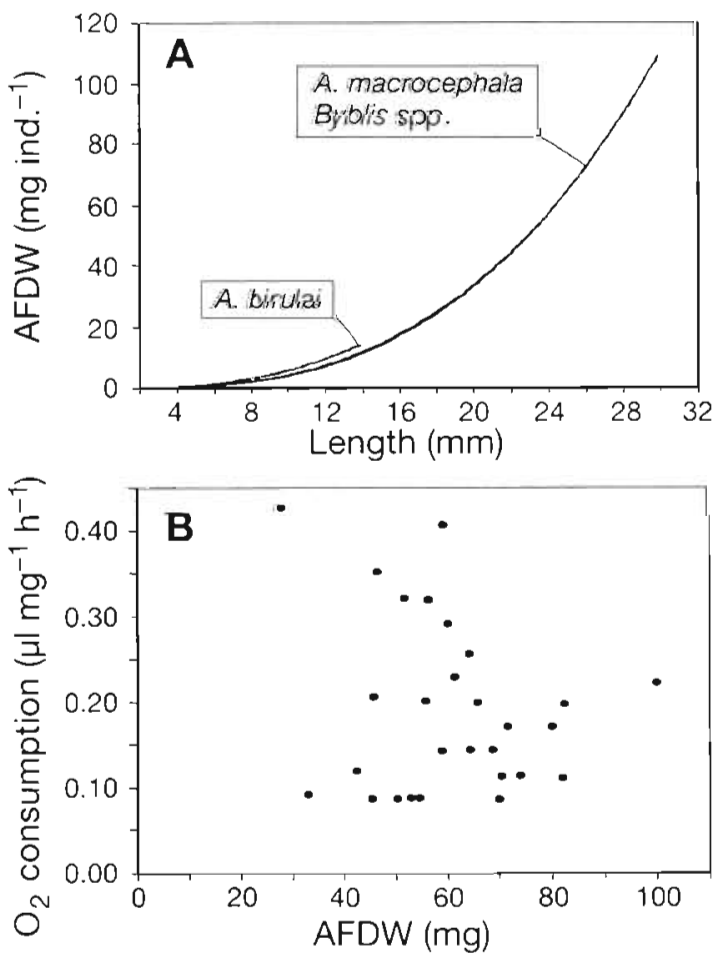

Fig. 1. (A) Regression of length vs ash free dry weight of Ampelisca macrocephala, A. birulai and Byblis spp. from the Chirikov Basin. Regression coefficients in Table 1A. (B) Oxygen consumption rate by $A$. macrocephala of different ash free dry weights 
the median length of each age class. The average effective foraging area of an individual in a given age class was estimated by:

$$
A=\pi\left(R L_{\mathrm{m}}\right)^{2}
$$

where $A$ is the area, $R$ is the $A / B$ ratio for a given taxon (Table $1 \mathrm{~B}$ ) and $L_{\mathrm{m}}$ is the median body length of the age class. The annual carbon requirement for each age class was divided by the foraging area, yielding estimates of the annual carbon flux (converted to $\mathrm{g} \mathrm{m}^{-2}$ ) required for ampeliscids in each size category to grow to the next size category in $1 \mathrm{yr}$ (Table 1C). Because the $\mathrm{A} / \mathrm{B}$ ratio ranged from 0.52 to 0.35 depending upon the species (Table 1B), fluxes for each of the 3 taxa are given. $A$. birulai requires the lowest carbon flux because it does not exceed $14 \mathrm{~mm}$ length and has the highest $A / B$ ratio. A. macrocephala requires the highest carbon flux due to its greater size (reaching $32 \mathrm{~mm}$ length) and lower $\mathrm{A} / \mathrm{B}$ ratio. Carbon flux requirements for Byblis gaimardi, which matures at about 18 to 20 $\mathrm{mm}$, are intermediate between the above 2 extremes. Although there is a rather broad carbon flux range over which one or another of the ampeliscid species inhabiting the Chirikov Basin could persist, decreases in organic input should impact the larger species before the smaller ones.

Another major consequence of large size in ampeliscids is an increase in the generation time. The effect of generation time on reproductive potential can be illustrated using the instantaneous rate of natural increase:

$$
\sum l_{x} m_{x} e^{-r x}=1
$$

where $l_{x}$ is the proportion of individuals that survive to reproductive age $x, m_{x}$ is the number of female offspring produced by an individual female while her age is between $x$ and $x+1, r$ is the instantaneous rate of natural increase and $x$ is the age of the reproducing female (Pielou 1974). Since, for comparison, the survival of all taxa is assumed to be 1 , and the majority of individuals breed once during their life, the above equation reduces to:

$$
m_{x} \mathrm{e}^{-r x}=1
$$

Reproductive potential was computed by substituting $f / 2$ for $m_{x}$, where $f$ is the number of eggs per female (assuming an equal sex ratio) and solving the above equation for $r$ :

$$
r=-\ln (2 / f) / x
$$

where $r$ is redefined as the reproductive potential, the instantaneous rate of increase assuming $I_{x}=1$ for all taxa. The equation for population growth is:

$$
N=N_{0} \mathrm{e}^{r t}
$$

where $N$ is the population at time $t$ and $N_{0}$ is the population at time $t=0$ (Pielou 1974). The above ampeliscid species mature somewhere between 2 and 5 yr of age, depending on their size. The fecundity estimates of ampeliscids vary considerably, since eggs are easily lost from the brood pouch during collection. The highest number of eggs recorded in Ampelisca macrocephala was 58 , but fecundity across the population may have been lower, because about $4 \%$ of the $A$. macrocephala and $A$. erythrorhabdota adult females were infested with nicothoid (Choniostomatidae) copepods, which consume crustacean eggs (Heron \& Damker 1986). A. erythrorhabdota had about 18 to 20 eggs female ${ }^{-1}$, when brood pouches appeared to be fuil. Model prediction (see below) indicated that $A$. birulai, A. macrocephala and Byblis spp. can coexist with fecundities of approximately $17-18,37$ and 35 eggs female ${ }^{-1}$ respectively. The brood time, a minimum of 5 mo (Highsmith \& Coyle 1991), was added to the age at maturity, yielding generation times of approximately $3,4,5$ and 6 yr for $A$. birulai, $A$. erythrorhabdota, Byblis spp. and A. macrocephala respectively.

The above data were used to compute a reproductive potential for the above taxa, and the ratio of Ampelisca macrocephala abundance to that of the other taxa was plotted against time (Fig. 2). For ease of comparison, A. macrocephala abundance was set at twice that of the other species, although A. macrocephala, A. birulai and Byblis spp. actually made up

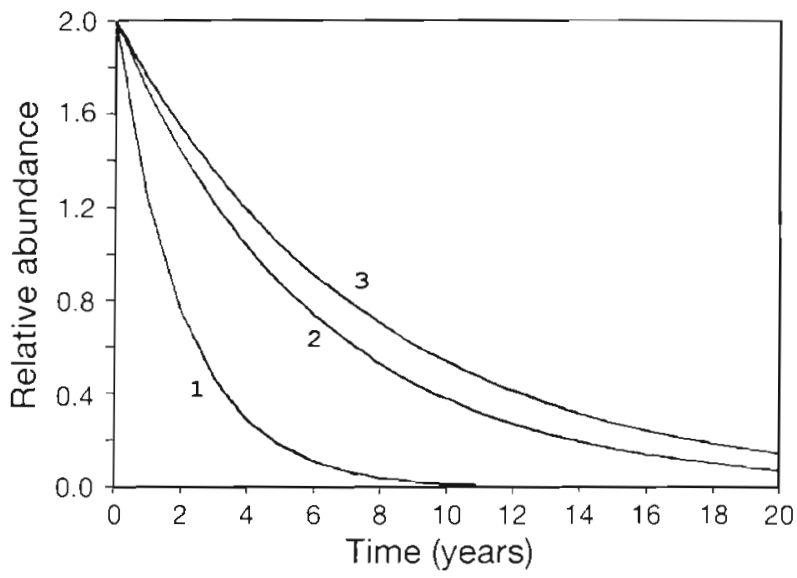

Fig. 2. Changes in the relative abundance of Ampelisca macrocephala with respect to $A$. birulai (1), A. erythrorhabdota $(2\}$ and Byblis gaimardi (3), assuming A. macrocephala density is twice that of the other taxa at time 0 and equal mortality for all taxa 
57, 19 and $24 \%$ of the population respectively (Highsmith \& Coyle 1992). All of the resulting curves have negative exponential slopes (Fig. 2). Thus, despite the greater fecundity of the larger species, with equal mortalities the smaller species would quickly supplant the larger ones because of shorter generation times. Therefore, the larger ampeliscids, which are actually dominant, must not only live in a highly productive environment, they must also have a lower mortality rate than smaller ampeliscids.

One advantage of larger size is the ability to defend limiting resources against smaller competitors. Competitive interactions influencing cohort survival and population structure have been demonstrated in the tube-dwelling amphipods Corophium volutator and $C$. arenarium, where individuals have been observed to force smaller animals from their tubes (Jensen \& Kristensen 1990). Elevated juvenile mortality of Monoporeia affinis in the presence of adults may be due to increased competition for food or predation by adults on juveniles (Hill 1992), and the lack of overlap between similar ampeliscid species in Long Island Sound (USA) is thought to be caused by competition for a limiting resource (Sanders 1956).

A resource which may be limiting in the Chirikov Basin is space. The amount of space available to these amphipods per square meter can be estimated from the size-frequency distribution of the populations of ampeliscid species at each station. Assuming that the maximum possible territory occupied by an individual of each taxon is a circle equal in radius to the second antenna length (Table $1 \mathrm{~B}$ ), the average surface area occupied by ampeliscids at 6 stations where ampeliscids were most abundant, during 6 cruises over a $3 \mathrm{yr}$ period, was estimated (Table 2). The results indicate that intense competition for space was probably occurring at Stns 5 and 6 during cruise HX082 and at Stn 5 during HX091, where nearly all the available space was occupied. Competition for space was probably much lower at other stations, where as little as $38 \%$ of the available space was occupied. If space competition is defined as the probability of a larger individual displacing a smaller individual, then the larger taxa will have the greatest competitive advantage at locations where the greatest proportion of the space is occupied. As the proportion of occupied space declines, the probability that larger individuals will displace smaller individuals drops, decreasing the competitive advantage of larger size. Displaced individuals are readily attacked by predatory lysianassid amphipods, Chionoecetes opilio, and other predators (observations from a submersible; Klaus et al. 1990). Thus, the proportion of available space may be a measure of intra- and interspecific size-related mortality rates.
Table 2. Mean area $\left(\mathrm{m}^{2}\right)$ required by ampeliscids per $\mathrm{m}^{2}$ of surface area at 6 stations during 6 cruises, assuming each animal occupies an area equivalent to that of a circle having a radius of 1 antenna length. Standard deviation in parentheses. A mean of 1 indicates all space is occupied. Values greater than 1 indicate crowding and reduced feeding area per amphipod

\begin{tabular}{|cccccccc|}
\hline \multirow{2}{*}{ Stn } & \multicolumn{7}{c}{ Cruise } \\
& HX082 & HX091 & HX099 & HX107 & HX113 & HX119 \\
\hline \multirow{2}{*}{3} & 0.64 & 0.52 & 0.46 & 0.51 & 0.58 & 0.53 \\
& $(0.10)$ & $(0.14)$ & $(0.06)$ & $(0.14)$ & $(0.11)$ & $(0.07)$ \\
4 & 0.49 & 0.51 & 0.54 & 0.43 & 0.65 & 0.82 \\
& $(0.13)$ & $(0.14)$ & $(0.11)$ & $(0.05)$ & $(0.09)$ & $(0.17)$ \\
5 & 1.02 & 1.02 & 0.73 & 0.57 & 0.61 & 0.38 \\
& $(0.29)$ & $(0.13)$ & $(0.13)$ & $(0.18)$ & $(0.11)$ & $(0.12)$ \\
6 & 1.00 & 0.66 & 0.84 & 0.67 & 0.79 & 0.63 \\
& $(0.15)$ & $(0.15)$ & $(0.05)$ & $(0.11)$ & $(0.13)$ & $(0.11)$ \\
9 & 0.50 & 0.59 & 0.37 & 0.37 & 0.47 & 0.72 \\
& $(0.10)$ & $(0.13)$ & $(0.09)$ & $(0.06)$ & $(0.10)$ & $(0.07)$ \\
10 & 0.73 & 0.55 & 0.54 & 0.40 & 0.68 & 0.54 \\
& $(0.08)$ & $(0.08)$ & $(0.08)$ & $(0.09)$ & $(0.04)$ & $(0.16)$ \\
& & & & & & \\
\hline
\end{tabular}

Assuming the major source of size-related mortality (loss from the population) is displacement of smaller individuals by larger ones, a model was constructed to simulate population densities of Ampelisca macrocephala for each age class. The size-related mortality experienced by individuals of a given age class was simulated by computing the average space occupied by larger individuals (from older age classes) and by other individuals of the same age class. The probability that an individual will find suitable space was assumed to be equal to the proportion of the area remaining; the radius used to compute area was equal to the length of the individual multiplied by a factor (labeled proximity coefficient) which could be modified to adjust model predictions to realistic values. Reproductive and growth rates were based on measurements made from field collections $\left(37\right.$ eggs female ${ }^{-1}$, growth rates were $4 \mathrm{~mm} \mathrm{yr}^{-1}$ from $5 \mathrm{~mm}$ hatchling size to $32 \mathrm{~mm}$; Highsmith \& Coyle 1991). Most ampeliscids produce 1 brood, but a small percentage of female $A$. macrocephala may produce a second brood (Kanneworff 1965), which was simulated in the model by assuming that $25 \%$ of the surviving females produce a second brood. Food was assumed not to be limiting.

The model was run with initial densities of each age class below 10 ind. $\mathrm{m}^{-2}$ and allowed to reach equilibrium. The proximity coefficient was adjusted to yield realistic population values. The densities of each age class initially increased and oscillated but came to equilibrium after about 120 iterations (Fig. 3). Each model iteration is equivalent to $1 \mathrm{yr}$. If the proximity coefficient was about 0.48 , the predicted population of each age class of Ampelisca macrocephala approached 


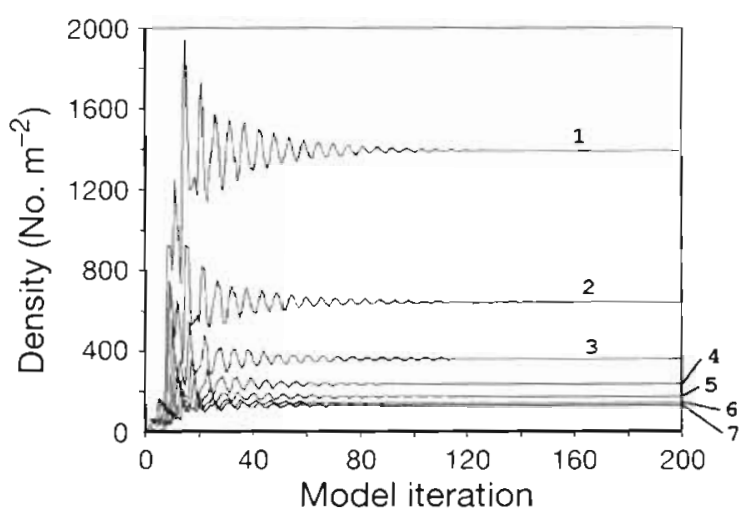

Fig. 3. Ampelisca macrocephala. Model prediction of age class densities, assuming space competition determines age class size. Lines 1 to 7 indicate age classes 1 to 7 respectively

the mean values measured at 6 stations for 6 cruises, although model predictions were slightly higher for age classes 1 and 7 (Table 3). Age class 1 was probably undersampled due to loss through the sieves during collection, and population losses in age class 7 may be higher than predicted due to senescent mortality. The model results suggest that age-related mortality caused by competition for space has the potential to set the relative abundance of each age class of $A$. macrocephala.

The proximity coefficient required by the model (0.48) exceeds the antenna length of Ampelisca macrocephala ( 0.35 of body length) because the model does not include $A$. birulai and Byblis spp., the other 2 abundant ampeliscids in the Chirikov Basin. The model was therefore refined to include the latter 2 taxa and to incorporate the effects of density independent predation mortality as well as competition between taxa. Predation was estimated by removing a constant percentage of individuals from all year classes each year. A growth rate of $4 \mathrm{~mm} \mathrm{yr}^{-1}$ and fecundity of 12 eggs female ${ }^{-1}$ was used for $A$. birulai, with maturity occurring in the third year. Values used for Byblis were

Table 3. Ampelisca macrocephala. Mean no. $\mathrm{m}^{-2}$ of amphipods in 7 age classes at 6 stations over $3 \mathrm{yr}$, and agefrequency distribution (no. $\mathrm{m}^{-2}$ ) projected by the model after reaching equilibrium with a proximity coefficient (proportion of body length) of 0.48

\begin{tabular}{|cccccccc|}
\hline & & \multicolumn{7}{c|}{ Age class } \\
& 1 & 2 & 3 & 4 & 5 & 6 & 7 \\
\hline Mean & 972 & 678 & 355 & 213 & 158 & 150 & 71 \\
$($ SD) & $(593)$ & $(410)$ & $(299)$ & $(136)$ & $(89)$ & $(64)$ & $(42)$ \\
Model & 1392 & 643 & 362 & 236 & 175 & 143 & 130 \\
\hline
\end{tabular}

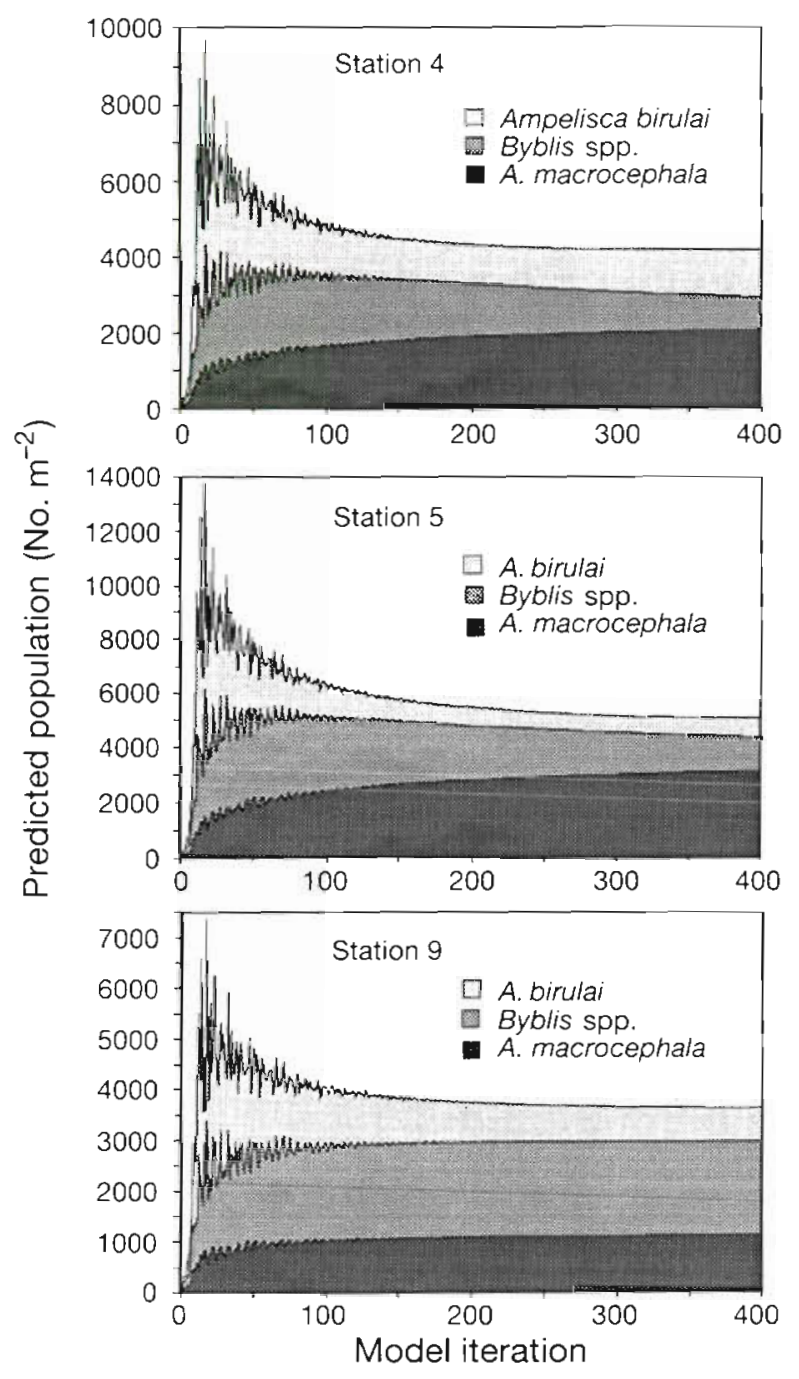

Fig. 4. Model simulations of ampeliscid densities at Stns 4,5 and 9 over 400 model iterations

$4 \mathrm{~mm} \mathrm{yr}^{-1}$ and 25 eggs female ${ }^{-1}$ with maturation in the fifth year. Initial densities of all 3 species were set below 10 ind. $\mathrm{m}^{-2}$ per age class. Fecundity, the proximity coefficient, and predation mortality were adjusted to bring simulated populations after 400 model iterations to levels approximately equal to average values observed at 3 stations over 6 cruises (Fig. 4 , Table 4). For graphic clarity, only the total densities of the 3 species were plotted.

To obtain realistic population estimates for all 3 species at these stations, the fecundity of Byblis gaimardi and Ampelisca birulai had to be elevated to 35 and 17.5 eggs female ${ }^{-1}$ respectively. Therefore, the maximum fecundity values determined from field samples were probably representative, with lower numbers resulting from egg losses during collection. With the above fecundity values held constant, small variations in the 
Table 4. Ampelisca macrocephala, A. birulai, Byblis spp Mean densities (no. $\mathrm{m}^{-2}$ ) for each age class of the 3 dominant ampeliscid taxa at 3 stations in the northern Bering Sea relative to model projections. Model parameters for each station are also shown

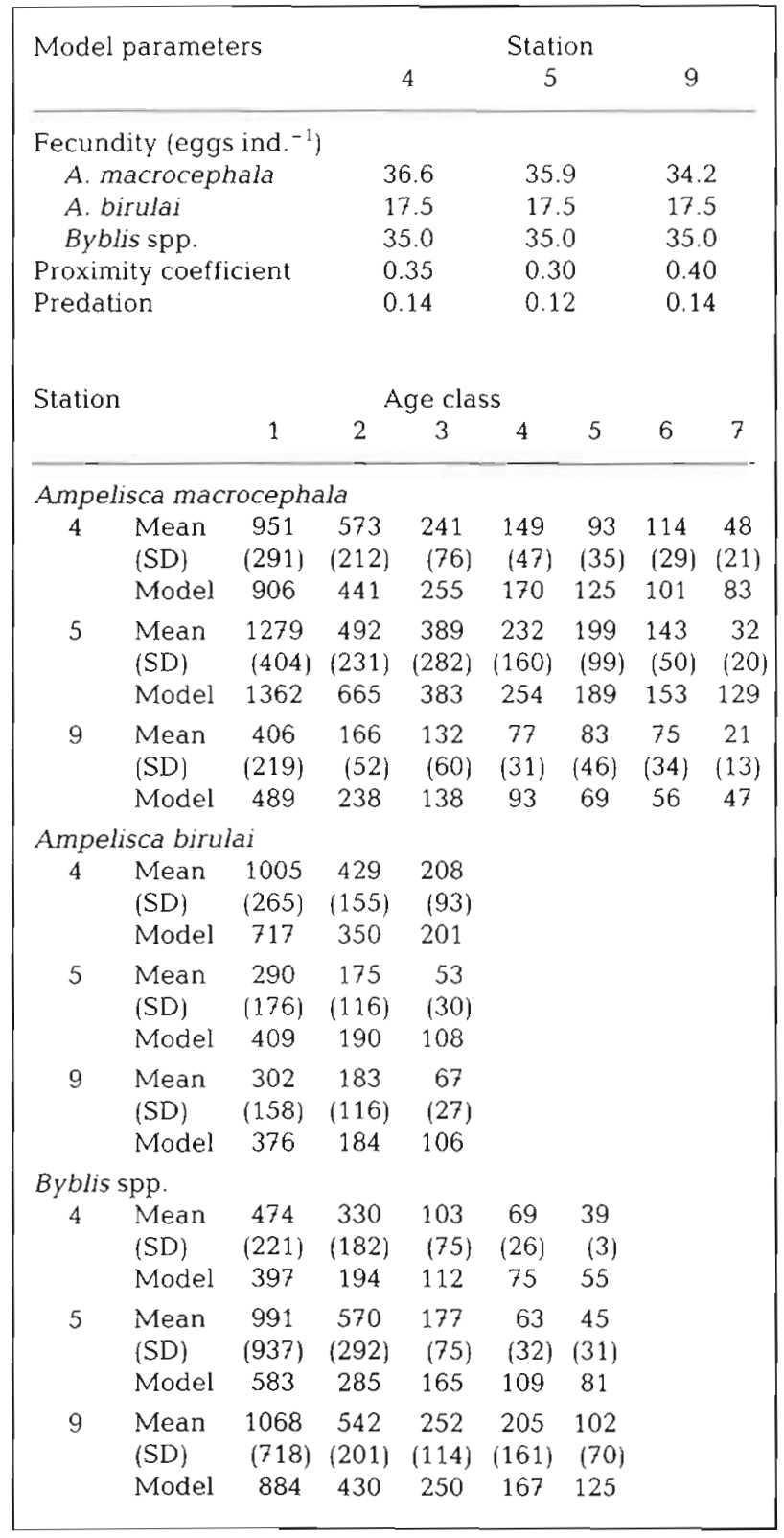

fecundity of $A$. macrocephala, the proximity coefficient and predation mortality yielded population estimates approximately equivalent to average values measured at the 3 stations (Table 4 ). The proximity coefficient ranged from 0.30 to 0.40 and was lowest at Stn 5, where A. macrocephala populations were greatest, and highest at Stn 9, where Byblis spp. dominated. A small decrease in $A$. macrocephala fecundity relative to Byblis spp. fecundity is sufficient for the latter species to out- compete the former $A$. birulai densities were highest at Stn 4 , where predation was highest and $A$. macrocephala densities exceeded Byblis spp. densities.

Average values of model parameters for the ampeliscid bed during the 3 yr study were computed as follows. The population of each taxon in each age class was averaged for the 6 stations and cruises listed in Table 2. Model parameters were then adjusted to yield predicted population densities in approximate agreement with field data after 400 iterations (Table 5). Predation mortality was set at $13 \%$ of each population per year, the proximity coefficient was set at 0.35 and Ampelisca macrocephala fecundity was set at 36 eggs female ${ }^{-1}$. Under these conditions, the model predicts an AFDW biomass for all taxa of $43 \mathrm{~g} \mathrm{~m}^{-2}$ compared with field estimates of $38 \mathrm{~g} \mathrm{~m}^{-2}$, computed from the AFDW regression and population data for the above 6 stations and cruises. The model predicts an AFDW production of $26 \mathrm{~g} \mathrm{~m}^{-2} \mathrm{Yr}^{-1}$, assuming constant mortality over the production season, compared with measured estimates of $25 \mathrm{~g} \mathrm{~m}^{-2} \mathrm{yr}^{-1}$ for a 6 mo production period (Highsmith \& Coyle 1992). The model predicts ampeliscid carbon consumption rates of 39 to $56 \mathrm{~g} \mathrm{C} \mathrm{m}^{-2} \mathrm{yr}^{-1}$ compared with measured estimates of $55 \mathrm{~g} \mathrm{C} \mathrm{m}^{-2} \mathrm{yr}^{-1}$ for the macrofaunal benthic community in the Chirikov Basin (Walsh et al. 1989). The model predicts a total AFDW loss to predation of $5.6 \mathrm{~g} \mathrm{~m}^{-2} \mathrm{yr}^{-1}$. Annual consumption of ampeliscids by gray whales is approximately $4.6 \mathrm{~g} \mathrm{~m}^{-2} \mathrm{ys}^{-1}$, converted from kcal to AFDW (Highsmith \& Coyle 1992).

The effect of an oscillation in predation rates, such as might have occurred due to gray whale hunting in the 19th through the mid-20th centuries (Henderson 1984) and the subsequent recovery of whale populations (Reilly et al. 1983), was simulated by a sine wave per-

Table 5. Mean densities (no. $\mathrm{m}^{-2}$ ) in each age class of the 3 dominant ampeliscid taxa at 6 stations during 6 cruises, and corresponding model predictions

\begin{tabular}{|c|c|c|c|c|c|c|c|}
\hline & \multicolumn{7}{|c|}{ Age class } \\
\hline & 1 & 2 & 3 & 4 & 5 & 6 & 7 \\
\hline \multicolumn{8}{|c|}{ Ampelisca macrocephala } \\
\hline Mean & 973 & 678 & 355 & 214 & 158 & 150 & 71 \\
\hline$(\mathrm{SD})$ & (593) & $(411)$ & $(229)$ & $(137)$ & (89) & $(64)$ & (43) \\
\hline Model pred. & 1262 & 615 & 356 & 237 & 175 & 142 & 119 \\
\hline \multicolumn{8}{|c|}{ Ampelisca birulai } \\
\hline Mean & 566 & 306 & 108 & & & & \\
\hline$(\mathrm{SD})$ & (391) & $(192)$ & (74) & & & & \\
\hline Model pred. & 659 & 319 & 181 & & & & \\
\hline \multicolumn{8}{|l|}{ Byblis spp. } \\
\hline Mean & 736 & 434 & 197 & 123 & 70 & & \\
\hline$(\mathrm{SD})$ & $(632)$ & $(263)$ & $(143)$ & $(110)$ & $(58)$ & & \\
\hline Model pred. & 660 & 322 & 187 & 125 & 92 & & \\
\hline
\end{tabular}



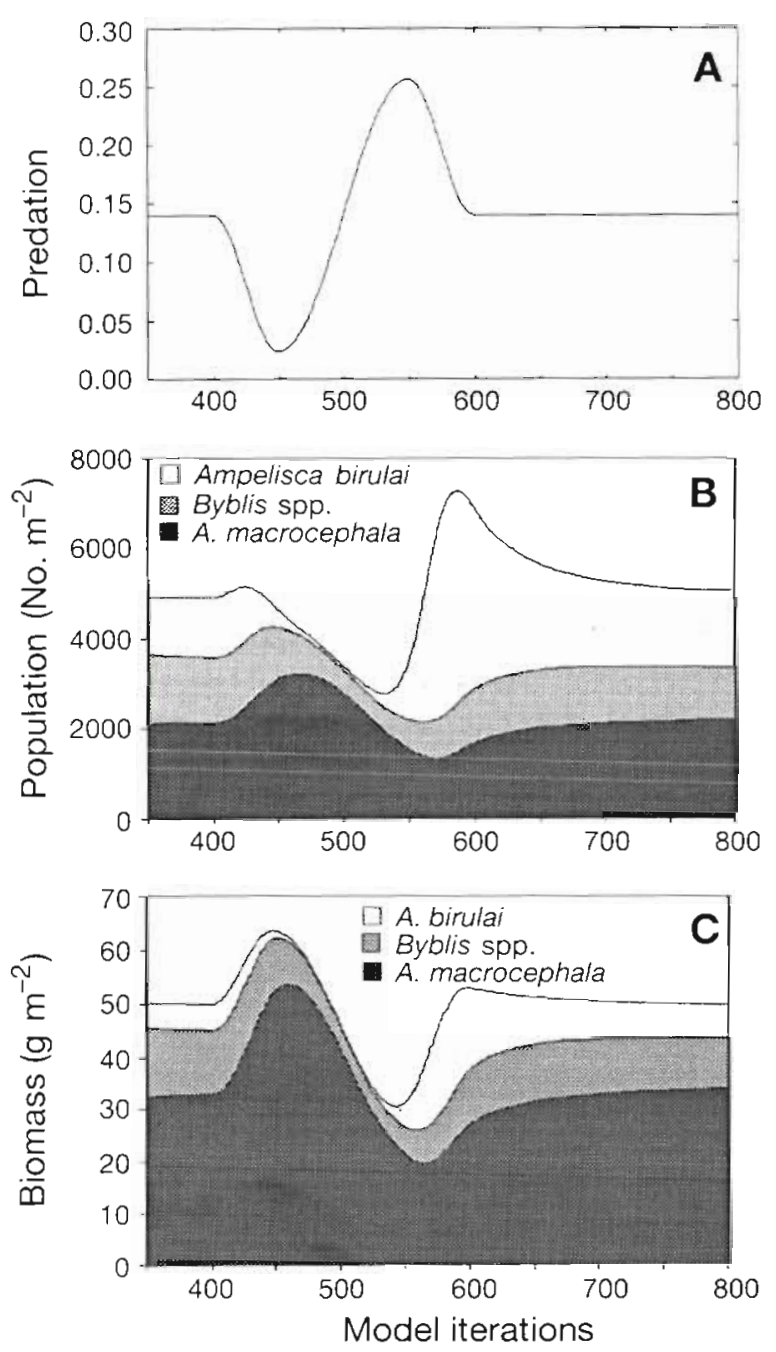

Fig. 5. Model simulation of the effect of a sine wave perturbation in predation rates on ampeliscid population and biomass after 400 model iterations. (A) Predation rates as a percentage of population; (B) ampeliscid populations; (C) ash free dry weight biomass

turbation in predation losses. Exact gray whale population data during the unregulated whaling period are not available. Historical catch data, however, indicate that the California gray whale population was reduced to about one-fourth of prewhaling numbers, from 20000 to 5000 animals (Henderson 1984). At the current rate of population growth, about $3 \% \mathrm{yr}^{-1}$, whales may take up to $25 \%$ of annual amphipod production by the year 2000 (Highsmith \& Coyle 1992). Model predictions, however, indicate that such removal rates are not sustainable. Simulations with a prewhaling predation rate of $14 \%$ yielded predicted ampeliscid densities during the late stages of whale recovery roughly equivalent to our field estimates. The amphipod model was initially run for 400 iterations with predation rate held constant at $14 \%$ of the total ampeliscid population per year. Between iterations 400 and 450 the predation rate was gradually decreased to about $3 \%$ of the population per year. Predation losses were then increased symmetrically from $3 \%$ to $26 \% \mathrm{yr}^{-1}$ between iterations 450 and 550 , and allowed to returned to $14 \%$ between iterations 550 and 600 (Fig. 5A). Decreased predation produced an increase in Ampelisca macrocephala density, a crash in the $A$. birulai population and a less severe dip in the Byblis spp. population (Fig. 5B). With a reduction in predation losses, the smaller amphipods in the simulation were unable to compete effectively for space with the larger individuals. After predation rates were increased between iterations 450 and 550 . A. birulai densities rapidly increased and Byblis spp. began a slower rebound. By iteration 600 , when predation again reached $14 \%$ of the total population per year, $A$. birulai densities were more than double their initial value before iteration 400. Over the next 150 iterations, $A$. birulai populations underwent a gradual decline, as Byblis spp. and A. macrocephala densities approached their initial values prior to iteration 400 . Despite the substantial population variations, the largest species, A. macrocephala, dominated amphipod biomass during the entire period (Fig. 5C). Since 1 model iteration is equivalent to 1 yr, the model predicts that perturbations in predation will have long-term effects (tens to hundreds of years) on these slowmaturing Arctic populations.

The simulated oscillation in predation caused an opposite fluctuation in ampeliscid carbon consumption and production, with amplitudes of only about $20 \%$ (Fig, 6A, B). When predation losses were returned to the equilibrium value at iteration 600, production and carbon consumption levels were nearly identical to those before the perturbation. When predation was maximum, the space occupied by ampeliscids underwent about a $50 \%$ decline (Fig. 6C).

Based on recent estimates of gray whale population growth, the whales should take 1.7 times more ampeliscids by the year 2000 (Highsmith \& Coyle 1992). If the predation rate had been held at the maximum of $26 \%$ of the population in the simulation, the densities and biomass of Ampelisca macrocephala, $A$. birulai and Byblis spp. after 800 iterations would have been 50,7600 and 1650 ind $\mathrm{m}^{-2}$, and 7,20 and $13 \mathrm{~g}$ $\mathrm{m}^{-2}$ respectively. Thus, $A$. macrocephala would have been essentially eliminated from the population. Total production at equilibrium following sustained predation at $26 \%$ would be lower than before, and roughly $65 \%$ of the production would be due to $\mathrm{A}$. birulai, the smallest ampeliscid with the highest reproductive potential. This scenario is unlikely, however, because these changes in ampeliscid densities would result in lower biomass and probably food limitation of the gray 

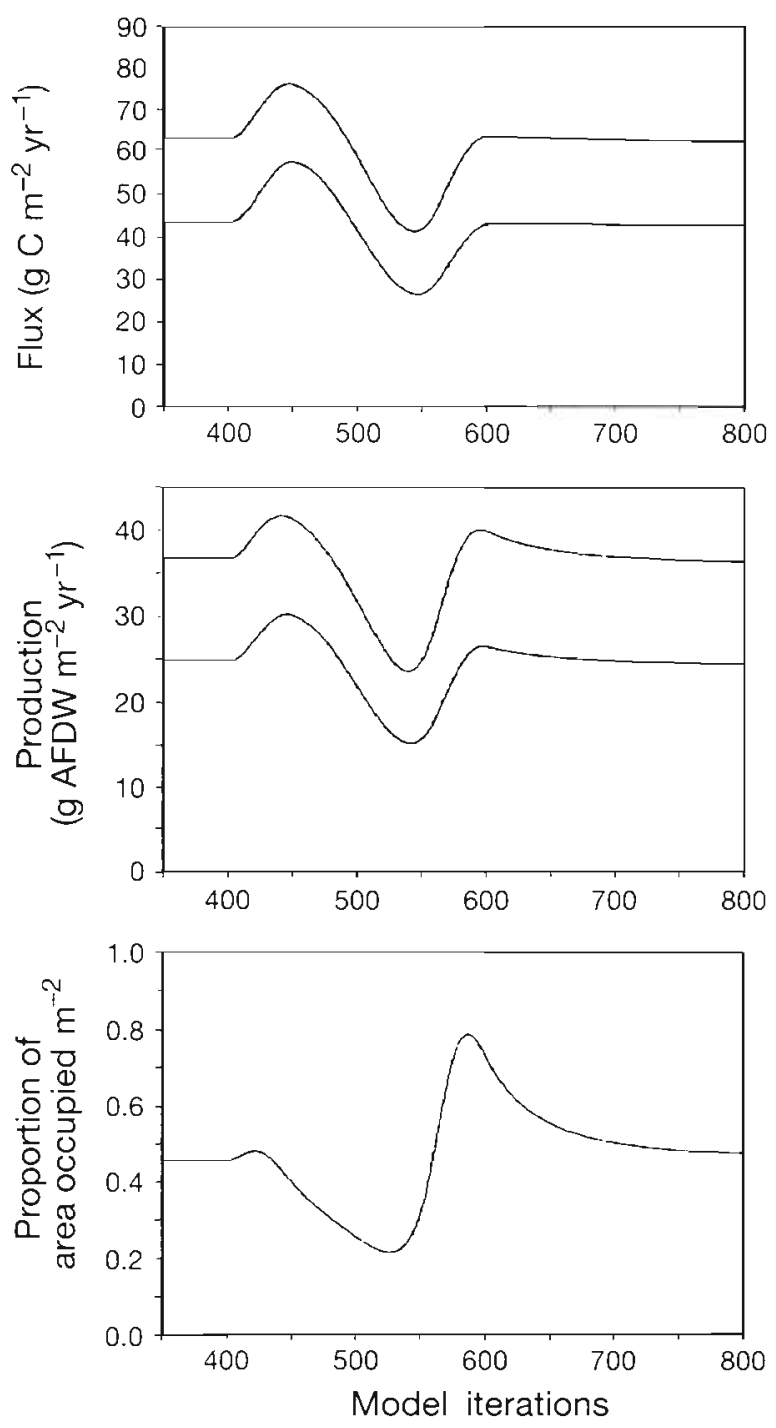

Fig. 6. Model simulation of the effect of a sine wave perturbation in predation rates on the carbon flux to the ampeliscid population, ash free dry weight production and maximum area occupied by ampeliscids. (A) Carbon flux. Upper line: maximum possible if all individuals survived to the next age class; lower line: flux if population is in approximate steady state. (B) Production. Line designations same as above. (C) Maximum possible area occupied $\left(\mathrm{m}^{2} \mathrm{~m}^{-2}\right.$ of surface area)

whales, causing their populations to decline, switch to other prey or forage elsewhere, thus reducing predation rates.

The actual ampeliscid density at which the gray whale population would become food limited is unknown. Since ampeliscids appear to have a patchy distribution, they may be an effective food source at lower average concentrations than might be predicted, if the whales can locate the patches. Nevertheless, the model does demonstrate the ampeliscid population trends likely to occur due to changes in whale predation.

\section{DISCUSSION}

The Chirikov Basin is an unusually productive region due to the transport of nutrient-rich Anadyr water northward from the Cape Navarin region through the Gulf of Anadyr and into the northern Bering Sea (Hansell et al. 1989, 1993, Springer \& McRoy 1993). The northward transport is due to differences in sea level between the Arctic Ocean and Bering Sea (Coachman 1993). Although some interannual differences in residence time of Anadyr Water in the Chirikov Basin can occur due to wind patterns in the Bering Strait regions, the overall transport during the production season is consistently northward (Coachman 1993). Because of the consistent northward transport of nutrient-rich water into the Chirikov Basin throughout the summer, the region has been likened to a continuous culture system (Sambroto et al. 1984). Total annual carbon production rates may be as high as 720 to $840 \mathrm{~g} \mathrm{C} \mathrm{m}^{-2} \mathrm{yr}^{-1}$ (Springer \& McRoy 1993), with new production rates of about $288 \mathrm{~g} \mathrm{~m}^{-2} \mathrm{yr}^{-1}$ in the Chirikov Basin (Hansell et al. 1993). The above production rates also show remarkable interannual continuity (Hansell et al. 1993). In addition to local production, substantial amounts of phytoplankton appear to be transported into the Chirikov Basin in the Anadyr water (Hansell et al. 1989). The combination of advection and high production leads to high carbon flux to the benthos, thus permitting dense concentrations of large ampeliscids to occur, which in turn provides favorable foraging habitat for gray whales. Benthic faunal structure and biomass have not changed significantly over a decade (Grebmeier et al. 1989), an additional indication of a persistent food supply to the benthos.

The relationship between ampeliscid size, carbon flux requirements, growth and molting rates limits the geographic distribution of large ampeliscids to cold, highly productive waters (Highsmith \& Coyle 1991). If molting rates and maturation accelerate due to increasing temperature and the number of molts to maturity is constant, as indicated in the literature (Highsmith \& Coyle 1991), temperate ampeliscids would require greater carbon flux to the seafloor to reach the same size as polar species because they would have to grow faster between the more frequent molts. Numerical comparisons of carbon flux requirements by faster-maturing temperate species and Arctic ampeliscids can be made by summing carbon flux estimates (Table 1) in adjacent age classes. For example, individuals maturing at 10 to $12 \mathrm{mo}$ of age and $12 \mathrm{~mm}$ length in 2 to $18^{\circ} \mathrm{C}$ water (near the Isle of Man and near Helgoland; Klein et al. 1975, Hastings 1981, Highsmith \& Coyle 1991) would require a minimum of about 116 to $168 \mathrm{~g} \mathrm{C} \mathrm{m}^{-2} \mathrm{yr}^{-1}$ depending on antenna 
length, at least 1.7 times the rate required by Ampelisca birulai to mature at the same size in the Chirikov Basin in 2 yr. A. macrocephala would require a minimum of $481 \mathrm{~g} \mathrm{C} \mathrm{m}^{-2} \mathrm{yr}^{-1}$ to mature at 20 to $28 \mathrm{~mm}$ length in temperate regions, assuming growth rates of about $8 \mathrm{~mm} \mathrm{yr}^{-1}$. A. macrocephala in the Øresund, mature in 1.5 (males) to $2 \mathrm{yr}$ (females), but the females only reach about $18 \mathrm{~mm}$ length (Kanneworff 1965). These A. macrocephala would require a minimum of about $327 \mathrm{~g} \mathrm{C} \mathrm{m}^{-2} \mathrm{yr}^{-1}$, but may have utilized an alternative food source, as Kanneworff (1965) reported much animal material and algal detritus in the diets. In highly dense populations, where nearest neighbors are closer than the length of the second antenna, the above flux estimates would have to be even higher to sustain the same growth rates. Alternatively, the same species could survive at lower flux rates by simply maturing at a smaller size.

Carbon flux to the detritus pool is approximately $231 \mathrm{~g} \mathrm{C} \mathrm{m}^{-2} \mathrm{yr}^{-1}$ in the Chirikov Basin under Anadyr water (Walsh et al. 1989), somewhat below the upper limit required for Ampelisca macrocephala to reach $28 \mathrm{~mm}$ length (Table 1). Carbon flux to macrobenthos in the Chirikov Basin is about $55 \mathrm{~g} \mathrm{C} \mathrm{m}^{-2} \mathrm{yr}^{-1}$, under Anadyr-Bering Shelf water (Walsh et al. 1989). The model predictions of ampeliscid population structure and biomass indicate a carbon utilization rate by ampeliscids of 39 to $57 \mathrm{~g} \mathrm{C} \mathrm{m}^{-2} \mathrm{yr}^{-1}$, roughly equivalent to the above estimate of carbon flux to macrobenthos. Total carbon flux to the detritus pool in Alaskan Coastal Water is only $30.5 \mathrm{~g} \mathrm{C} \mathrm{m}^{-2} \mathrm{yr}^{-1}$ (Walsh et al. 1989 ), about $50 \%$ below that required by $A$. birulai, the most efficient ampeliscid forager in our study, to mature and reproduce (Table 1C). Carbon flux data and model predictions therefore indicate that ampeliscids cannot survive in areas of the Chirikov Basin overlain by Alaskan Coastal Water because carbon flux to the bottom is too low to sustain them.

Broad scale examination of benthic community structure in the Chirikov Basin confirms the absence of the ampeliscid community under Alaskan Coastal Water (Grebmeier et al. 1988, 1989). Although the sediment composition under Alaskan Coastal Water is somewhat different from that in the ampeliscid bed (Naidu 1988, Grebmeier et al. 1989), these sediment differences do not appear to explain the absence of ampeliscids under Alaskan Coastal Water because ampeliscids are present and sometimes abundant off Pt. Franklin (northern Chukchi Sea), where sediment composition is nearly identical to that under Alaskan Coastal Water in the Chirikov Basin (Klaus et al. 1990, Feder et al. 1991). Therefore, the absence of the ampeliscid community under Alaskan Coastal Water is probably due primarily to food limitation rather than sediment composition.
In field samples, Ampelisca macrocephala dominated ampeliscid populations at all sites within the ampeliscid bed, except at the southeast corner $\left(64^{\circ} \mathrm{N}\right.$, $168^{\circ} \mathrm{W}$ ), where Byblis spp. dominated. Byblis spp. dominance was simulated in the model by lowering the fecundity of $A$. macrocephala (Table 4). Decreases in A. macrocephala fecundity might result from lower carbon flux to the sea bed, as any decrease in carbon flux will influence the larger species before the smaller ones. Lower carbon sedimentation rates occur near the eastern edge of the ampeliscid bed, a transition zone between the Anadyr and less productive Alaskan Coastal Water masses (Walsh et al. 1989). Thus, lower carbon flux on the eastern edge of the Chirikov Basin may give Byblis spp. a competitive advantage, allowing it to dominate in that region.

Model simulations producing population estimates in approximate agreement with average ampeliscid densities observed in the Chirikov Basin from 1986 to 1988 require a predation loss of roughly $13 \%$ of the biomass per year, approximately $5.6 \mathrm{~g} \mathrm{AFDW} \mathrm{m}^{-2} \mathrm{yr}^{-1}$. Gray whales, major predators on ampeliscid populations, removed about 8 to $18 \%$ of the annual ampeliscid production between 1986 and 1988 (Highsmith \& Coyle 1992), equivalent to approximately 2.4 to $5.4 \mathrm{~g}$ AFDW $\mathrm{m}^{-2} \mathrm{yr}^{-1}$. Other predators taking the remaining losses include fish, decapods and lysianassid amphipods (authors' unpubl. data). For steady state populations, maximum possible losses to predators would be $8.4 \mathrm{~g} \mathrm{dry} \mathrm{wt} \mathrm{m}^{-2} \mathrm{yr}^{-1}$ or about $4.2 \mathrm{~g} \mathrm{C} \mathrm{m}^{-2}$ $\mathrm{yr}^{-1}$. Walsh et al. (1989) predict a carbon loss from benthic macrofauna to apex vertebrate predators of $5 \mathrm{~g} \mathrm{C}$ $\mathrm{m}^{-2} \mathrm{yr}^{-1}$ in Anadyr water.

Polar amplification of global warming may cause an increase in average annual temperatures in Arctic waters (Schlesinger \& Mitchell 1987, Sarmiento et al. 1988), which could affect Arctic ampeliscid populations in 2 ways. Warmer bottom water temperatures should accelerate ampeliscid maturation rates (Highsmith \& Coyle 1991). If carbon flux to the benthos remained constant or decreased, Ampelisca macrocephala would mature at a smaller size or be replaced by smaller taxa. Therefore, A. erythrorhabdota, Byblis gaimardi, A. birulai or some other taxon (e.g. Echinarachnius parma; Highsmith \& Coyle 1991) would probably become the dominant primary consumer.

Many abundant commercial fish species from Bristol Bay are essentially excluded from more northern regions due to cold near-bottom water temperatures (Moiseyev 1964, Smith 1981, Bakkala 1981). Warmer conditions might permit them to extend their range northward into the Chirikov Basin, thus elevating predation on the ampeliscid community and increasing selective pressures for smaller, faster-maturing taxa. The immigration of additional temperate predator taxa 
might also increase competition between gray whales, fish and decapod predators for the ampeliscid food resource.

Acknowledgements. We greatly appreciate the contributions to this work of Carol Winiecke, Tama Rucker, J. McDonald and A. J. Paul; several students including F. Adams, A. Blanchard, J. Carpenter, S. Clay, M. Derenoff, D. Ferris, S. Fox, S. Hartz, T Henry, H. Kim, G. Koontz, B. Leal, G. Owens, P. Ribbens, F. Rivers, L. Shelley, C. Saccheus, C. Sullivan, T. Sundown, S. Vereck, J. Warburton and $\mathrm{K}$. Weller; the entire crew of the RV 'Alpha Helix'; marine technicians D. Boisseau, S. Ellis, D. Leech and M. Testarmata ${ }_{j}$ and anonymous reviewers for constructive comments. This research was supported by the National Science Foundation, Office of Polar Programs, grant DPP-8509843, and NOAA's National Undersea Research Program through the West Coast National Undersea Research Center at the University of Alaska, Fairbanks.

\section{LITERATURE CITED}

Bakkala, R. G. (1981). Population characteristics and ecology of yellowfin sole. In: Hood, D. W., Clader, J. A. (ed.) The eastern Bering Sea shelf: oceanography and resources, Vol. 1. University of Washington Press, Seattle, p. 553-574

Blokhin, S. A., Vladimirov, V. L. (1981). Pitanie serykh kitov Kaliforniisko-Chukotskoi populyatsii $\mathrm{v}$ vodakh Chuktskogo poluostrogo v $1980 \mathrm{~g}$. (The diet of the CaliforniaChukotsk gray whale population in Chukchi Peninsula waters in 1980.) In: Nauchno-issledovatelskie raboty po morskim mlekopitayushchim severnoi chasti Tikhogo okeana v 1980/1981 gg. Proekt 02.05-61 Morskie mlekopitayushchie, Soglasheniya SSSR-ShA o sotrudnichestve v oblasti okhrany okruzhayushchei sredi. Moscow, p. 88-98

Coachman, L. K. (1993). On the flow fields in the Chirikov Basin. Cont. Shelf Res. 13(5/6): 481-508

Coachman, L. K., Agaard, K, Tripp, R. B. (1975). Bering Strait. The regional physical oceanography. Univ. of Washington Press, Seattle

Coachman, L. K., Hansell, D. A. (eds.). (1993). ISHTAR. Inner shelf transfer and recycling in the Bering and Chukchi Seas. Cont. Shelf Res. 13(5/6): 473-704

Coyle, K. O., Highsmith, R. C. (1989). Arctic ampeliscid amphipods, three new species. J. Crust. Biol. 9: 157-175

Feder, H. M., Naidu, A. S., Hameedi, J. M., Jewett, S. C., Johnson, W. R. (1991). The Chukchi Sea continental shelf: benthos and environmental interactions. Final Report. Outer Continental Shelf Environmental Assessment Program, Vol. 68. U.S. Dept of Commerce, National Oceanic and Atmospheric Administrations, Washington, DC, $p$. 25-311

Grebmeier, J. M., Feder, H. M., McRoy, C. P. (1989). Pelagicbenthic coupling on the shelf of the northern Bering and Chukchi Seas. II. Benthic community structure. Mar. Ecol. Prog. Ser. 51: 253-268

Grebmeier, J. M., McRoy, C. P., Feder, H. M. (1988). Pelagicbenthic coupling on the shelf of the northern Bering and Chukchi Seas. I. Food supply source and benthic biomass Mar. Ecol. Prog. Ser. 48: 57-67

Hansell, D. A., Goering, J. J., Walsh, J. J., McRoy, C. P., Coachman, L. K., Whitledge, T E. (1989). Summer phytoplankton production and transport along the shelf break in the Bering Sea. Cont. Shelf. Res. 9: 1058-1104

Hansell, D. A., Whitledge, T. E., Goering, J. J. (1993). Patterns of nitrate utilization and new production over the BeringChukchi shelf. Cont. Shelf Res. 13(5/6): 601-627

Hastings, M. N. (1981). The life cycle and productivity of an intertidal population of the amphipod Ampelisca brevicornis. Estuar. coast. Shelf Sci. 12: 665-667

Henderson, D. A. (1984). Nineteenth century gray whaling: grounds, catches and kills, practices and depletion of the whale population. In: Jones, M. L., Swartz, S. L., Leatherwood, S. (eds.) The gray whale Eschrichtius robustus. Academic Press, New York, p. 159-186

Heron, G. A., Damker, D. M. (1986). A new nicothoid copepod parasitic on mysids from northwestern North America. J. Crust. Biol. 6(4): 652-665

Highsmith, R. C., Coyle, K. O. (1990). High productivity of northern Bering Sea amphipods. Nature 344: 862-864

Highsmith, R. C.. Coyle, K. O. (1991). Amphipod life histories: community structure, impact of temperature on decoupled growth and maturation rates, productivity and $\mathrm{P}: \mathrm{B}$ ratios. Am. Zool. 31: 861-873

Highsmith, R. C., Coyle, K. O. (1992). Productivity of arctic amphipods relative to gray whale energy requirements. Mar. Ecol. Prog. Ser. 83: 141-150

Hill, C. (1992). Interactions between year classes in the benthic amphipod Monoporeia affinis: effects on juvenile survival and growth. Oecologia 91: 157-162

Jensen, K. T., Kristensen, L. D. (1990). Field experiment on competition between Corophium volutator (Pallas) and Corophium arenarium Crawford (Crustacea: Amphipoda): effects on survival, reproduction and recruitment. J. exp. mar. Biol. Ecol. 137: 1-24

Kanneworff, E. (1965). Life cycle, food, and growth of the amphipod Ampelisca macrocephala Liljeborg from the Oresund. Ophelia 2(2): 305-318

Klaus, A. D., Oliver, J. S., Kvitek, R. G. (1990). The effects of gray whale, walrus, and ice gouging disturbance on benthic communities in the Bering Sea and Chukchi Sea, Alaska. Nat. Geogr. Res. 6(4): 470-484

Klein, G., Rachor, E., Gerlach, S. A. (1975). Dynamics of productivity of two populations of the benthic tube-dwelling amphipod Ampelisca brevicornis (Costa) in Helgoland Bight. Ophelia 14: 139-159

Moiseyev, P. A. (1964). Nekotorye itogi issledovaniy beringovomorskiy nauchno-promyslovoy ekspeditsii. In: Sovetskiye rybokhozyaystvennye issledovaniya $v$ severovostochnoy chasti Tikhogo okeana, TINRO, No. 3. Pishchevaya Promyshlennost, Moscow, p. 7-29

Naidu, S. A. (1988). Marine surficial sediments. In: Bering, Chukchi and Beaufort Sea strategic assessment: data atlas No. 1.4. Office of Oceanography and Marine Assessment, National Oceanic and Atmospheric Administration, U.S. Dept of Commerce, Washington, DC

Nerini, M. (1984). A review of gray whale feeding ecology. In: Jones, M. L., Swartz, S. L., Leatherwood, S. (eds.) The gray whale Eschrichtius robustus. Academic Press, New York, p. $423-450$

Pielou, P. E. (1974). Population and community ecology. Gordon and Breach Science Publishers, New York

Reilly, S. B., Rice, E. W., Wolman, A. A. (1983). Population assessment of the gray whale, Eschrichtius robustus, from California shore censuses, 1967-1980. Fish. Bull. U.S. 81: $267-281$

Sambroto, R. N., Goering, J. J., McRoy, C. P. (1984). Large yearly production of phytoplankton in the western Bering Strait. Science 244: 1147-1150

Sanders, H. L. (1956). Oceanography of Long Island Sound, 1952-1954. X. The biology of marine bottom communities. Bull. Bingham Oceanogr. Coll. 15: 345-414 
Sarmiento, J. L., Toggweiler, J. R., Najja, R. (1988). Ocean carbon-cycle dynamics and atmospheric $\mathrm{CO}_{2}$. Phil. Trans. $\mathrm{R}$. Soc. Lond. 352: 3-21

Schlesinger, M. E., Mitchell, J. F. B. (1987). Climate model simulations of the equilibrium response to increased carbon dioxide. Rev. Geophys. 25: 760-798

Smith, G. B. (1981). The biology of walleye pollock. In: Hood, D. W. Calder, J. A. (eds.) The eastern Bering Sea shelf: oceanography and resources, Vol. 1 University of Washington Press, Seattle, p. 527-552

Springer, A. M., McRoy, C. P. (1993). The paradox of pelagic food webs in the northern Bering Sea. III. Patterns of pri-

This article was submitted to the editor mary production. Cont. Shelf Res. 13(5/6): 575-599

Stoker, S. W. (1981). Benthic invertebrate macrofauna of the eastern Bering/Chukchi continental shelf. In: Hood, D. W. Calder, J. A. (eds.) The eastern Bering Sea shelf: oceanography and resources, Vol. 2. Univ. of Washington Press, Seattle, p. 1069-1090

Strickland, J D. H., Parsons, T R. (1972). A practical handbook of seawater analysis. Bull. Fish. Res. Bd Can. 167

Walsh, J., and 19 co-authors (1989). Carbon and nitrogen cycling within the Bering/Chukchi Seas: source regions for organic matter affecting AOU demands of the Arctic Ocean. Prog. Oceanogr. 22: 277-359

Manuscript first received: September 6, 1993 Revised version accepted: January 26, 1994 